\title{
Potential of Fresh Water Supply in Developing Countries
}

\author{
A. Sidani, and M. Youssef
}

\begin{abstract}
Earth through the last decades is the obvious shortage and waste of fresh water. Unfortunately, countries miss used its fresh water resources which affected negatively its inhabitants and ecosystem. Science of landscape architecture succeeded in finding solutions to improve the usage of fresh water, on local and regional scales. This paper therefore aims to detect these solutions and approaches that could be applied to functioning fresh water resources. Valuable case studies will be examined on international level in Netherlands and Singapore, to analyze their approaches. This paper will test how these approaches can be applied in Lebanon. One of the most important conclusions is water development and water management will be important for Lebanon and the developing countries to have fresh water in the future.
\end{abstract}

Keywords-Environmental impact, Fresh water, Water Crises, water sources.

\section{INTRODUCTION}

The increasing demands of clean water in the developing countries, threaten the biodiversity and human needs to survive, towns and cities in such countries are under a severe environmental stress [1]. Cities have grown over past decades due to migration, increase in trade, tourism, and other activities. This created overpopulation in urban areas more than they could handle. Drinking water and sanitation facilities are being hard to provide for the high number of citizens [2]. The water supply and sanitation systems in developed countries are facing the following issues:

- Existing sources are exhausted or polluted, so raw water is transported from distant source; this consumes energy due to transportation.

- Treatments which include harmful chemicals are used for polluted water.

- Surface water source such as a river is exploited to such an extent that it cannot meet ecological flow demand at downstream reach.

- Ground water is being polluted by the discharge of waste water without treatment.

In addition to the above concerns, coastal cities are threatened by rise and intrusion of sea water, affecting groundwater aquifers.

Manuscript received Nov. 10, 2015. This work was supported in part by the Beirut Arab University under Dr. Maged Youssef (sponsor and financial support acknowledgment goes here).

F. A. Sdani is with the Faculty of Architectural Engineering, Beirut Arab University, Lebanon.

Maged Youssef is with the Faculty of Architectural Engineering, Beirut Arab University, Lebanon.
In the near future, climate change and rise of sea level will make more complications for this problem. In other words, coastal cities are faced with increased energy consumption, water pollution, resource depletion, waste generation and eutrophication [3]. This paper tries to investigate the interaction of environmental issues relating to fresh water supply in developing countries. The use of two case studies "Singapore and Netherlands" is to identify their approaches. The paper evaluates existing systems, presents their efficiency, environmental impact, and their new innovated applied research, like dual membrane system Anammox, and Pharmfilter, which are cost efficient and sustainable methods that could be used to help solving water problems in the developing countries. Millennium Development Goals Report 2012 stated that 783 million people, or $11.5 \%$ of the global population, have no access to an improved supply of drinking water. Such supplies include public standpipes, household connections, protected springs, boreholes, treated wells, and rainwater collections systems [4]. Furthermore, there are regions still undeveloped such as Sub-Saharan Africa, where over $45 \%$ of the people without good drinking water [5].

The United Nations have long been dealing with the global crisis caused by insufficient water supply to satisfy essential human needs and rising demands on the world's water resources to meet human, and agricultural needs. The United Nations Water Conference held in 1977, the International Conference on Water and the Environment held in 1992, the Earth Summit in 1992, and many others all focused on this vital resource. The sanitation Decade, in particular, helped some 1.3 billion people in developing countries gain access to fresh water [6]. On July 2010 "The General Assembly of the human right to water and sanitation" had been recognized by the United Nations, this Assembly states that every person should have the right to have accessibility to fresh water, safe to drink and affordable, the water source should be within $1 \mathrm{~km}$ and should not exceed 30min to reach, with sufficient quantity of 50L to $100 \mathrm{~L}$ per person per day [6]. The General Assembly is trying to help raising the public awareness of the importance of water for life, it declared 2003 International Year of Fresh Water, in addition to the United Nation's Chief Executive Board established UN Water, an agency for managing all fresh water and sanitation related problems, to raise more public awareness [6]. The united nations are actively working on projects that focus on managing natural water resources in a sustainable way, which are under increase stress dense population, pollution and the industrial and agricultural demands. In this paper, firstly water is explained in terms of numbers with respect to population and future development. Secondly, an analysis of current situation and issues of water 
supply. Thirdly, environmental effects of these issues are discussed followed by an assessment of fresh water quality and availability. Finally, analyzing two case studies and comparing them to come up with the most efficient methods and strategies, to sustain fresh water and the ecosystem. And encourage developing countries to have similar approaches for managing water.

\section{WATER THE ESSENTIAL SOURCE FOR LIFE}

\section{A. Benefits of water}

Water is the essential source of life on Earth, there are unlimited benefits for water, earliest life forms appeared in water, and all living things depend on it. Water cycle plays many roles in climate, chemistry, and biology of Earth; nevertheless it is essential part of photosynthesis, and metabolic process in the bodies of all living things. Early civilizations expanded on water sources and rivers, from Ancient Egyptian and Mesopotamian civilizations, to the more recent cities including New-York, Tokyo, Montreal, London, Paris etc. These cities flourished on water cites by using them from basic human needs like drinking and hygiene to transportation. Humans rely on water for different uses like drinking, agriculture, washing, chemical use, recreational, fire extinguishing, heat transfer, electric generation and transportation. Water is a renewable source; the main source of water is rain and snow, forms in the hydrologic cycle the process of evaporation of surface water. This fresh water is then stored as ice or in rivers, lakes or underground. Since Fresh water is so essential to life on Earth, it is important to protect the water storages, some parts of the world have short fresh water supply.

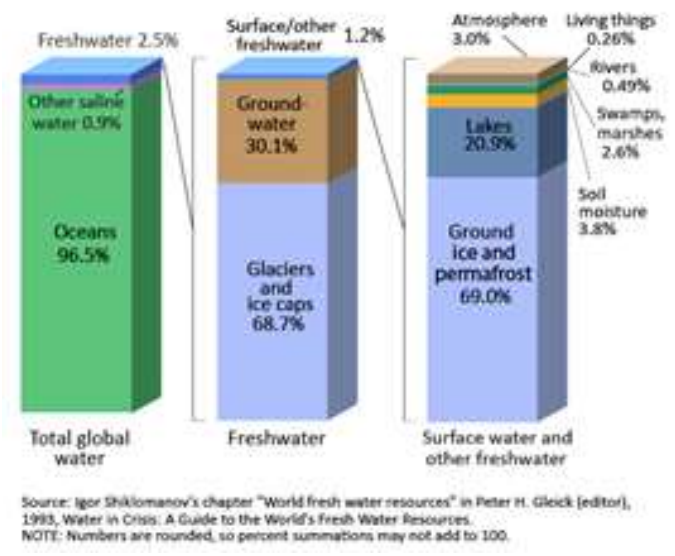

Fig. 1: Water natural resources on Earth

\section{B. Freshwater supply}

While water is a renewable source, its supply is limited, due to the high consumption and the world rapid population growth increased the consumption of fresh water [7], which became a major global issue. Water demand is rising because of urbanization, economic development, and improved living standards. In many countries, and especially developing countries, water mismanagement and water withdrawal is too high, lakes and rivers are the main disposal site for wastes including untreated or partially treated sewage, industrial poisons, and harmful chemicals that leaks into surface and ground water during agricultural activities. Increasing in population and pollution of fresh water resources are directly related. Growth of population will change availability of fresh water for drinking, household consumption, food and beverage production, and industrial and medical uses. In the same manner pollution and water depletion are related, the increase in demand and overuse of resources leads to pollution and depletion. This kill over 12 million people a year [2], and will cause critical health problems, like cholera, hepatitis malaria fevers, etc. nevertheless social and political tensions are also caused by water shortage. In less than 30 years, 50 countries could face serious water shortages, affecting about 3.3 billion people worldwide [8].

\section{Hydrologic Cycle}

Also known as water cycle, this cycle is based on the solar radiation that evaporates water, $86 \%$ from the sea and the rest from land water, in this phase water is purified, when we receive water as rain and sometimes in form of snow, fog, hail, drip, and sleet. $78 \% 398,000 \mathrm{~km}^{3}$ falls on the sea and 107,000 $\mathrm{km}^{3}$ falls on land, approximate total of $505,000 \mathrm{~km}^{3}$ of waterfall each year [9]. Water can change from a state to another and from one storage source to another. It can be stored as ice or liquid in rivers lakes, reservoirs, sea etc. This variation occurs due to climate change. In this process more sea water is evaporated and $8 \%$ falls on the land each year, which is a significant portion of water from oceans to land areas [9]. Hydrologic cycle is important for survival of all living beings.

\section{Availability of water}

As stated hydrologic cycle purifies water and return in to land as fresh water source, it is renewable, average precipitation for most continents are about $700 \mathrm{~mm}$ per year [10]. The problem is that the amount of waterfall varies from time to time and from continent to another, for Africa $640 \mathrm{~mm}$ per year is very low, in addition to the hot climate which triggers rapid evaporation [11]. The average amount of water is one million liters per person per year. Nevertheless 9 of 14 Middle Eastern countries like Egypt, Saudi Arabia, Iraq, Israel, Jordan, Syria, and Iran have insufficient fresh water [12]. Access to safe water is e basic human right. Water must be managed wisely to be sure everyone will have access to fresh water that is easily accessible, affordable and safe.

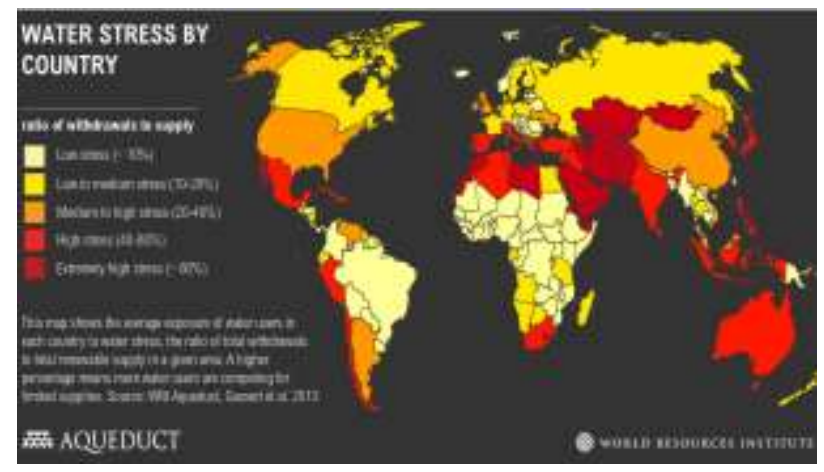

Fig. 2: Map of water stress by countries 


\section{E. Methods of supplying fresh water}

There are three ways to supply water it can be done by traditional infrastructure piping, rainwater catchment and treatment, or water reclamation process. Sources of water include:

- Rainwater, collected and treated

- Desalination of Seawater

- Reclaimed water, which is purified to a degree to use in irrigation and industrial use, it might be ultra-purified to get good quality drinking water

Water can be supplied by decentralized systems. According to each municipality, supply fresh water from the mentioned sources after treatment by traditional piping systems to its respected region. In addition the reclamation process is being used increasingly by many countries including Japan, Netherlands and Singapore. Many old cities mainly in Europe are equipped with central infrastructure to supply collected and reclaimed water [13]. In addition rain water is collected in tanks by water companies, and in house tanks without treatment used for irrigation and toilet. Rainwater is collected in natural and man-made aquifers. Research facilities and universities develop other strategies, like in Netherlands the membrane technology, anaerobic water purification, membrane bioreactor and Anammox technology, which is bacteria that help in converting chemical in wastewater into nitrogen gas. In Singapore, researches achieved to transform reclaimed water into ultrapure drinking water called NEWater, relies on advanced microfiltration, reverse osmosis and ultraviolet exposure to clean and treat wastewater. NEWater has been recognized as an international model for innovation in water management, they won the Environmental Contribution of the Year award.

\section{DESIGN CRITERIA}

Based on the preceding, it can be concluded specific design criteria that may be used in analyzing the following case studies shown in table 1.

TABLE I: DESIGN CRITERIA OF WATER SUPPLY

\begin{tabular}{ccccl}
\hline \hline Locations & Date & $\begin{array}{c}\text { Annual } \\
\text { Budget }\end{array}$ & $\begin{array}{c}\text { Population } \\
\text { supply }\end{array}$ & Methods of supply \\
\hline $\begin{array}{c}\text { 1. Far east } \\
\text { region }\end{array}$ & $\begin{array}{c}1980 \mathrm{~s} \\
-2015\end{array}$ & $\begin{array}{l}609 \$ \mathrm{~m} \\
\text { illion }\end{array}$ & $5,535,000$ & $\begin{array}{l}\text { Desalination } \\
\text { Reclaimed water } \\
\text { Water catchment } \\
\text { Imported water }\end{array}$ \\
2. Europe & $1850 \mathrm{~s}$ & $\begin{array}{l}\text { 348S } \\
\text { million }\end{array}$ & $16,929,326$ & $\begin{array}{l}\text { Underground water } \\
\text { New filtration methods }\end{array}$ \\
& -2013 & & \\
\hline \hline
\end{tabular}

\section{Case Studies}

\section{A. First case study: Experience of Singapore}

Experience of Singapore has to supply fresh water could be applied to a lot of developing countries since they took astonishing measures to have sufficient fresh water resources for ages to come. Singapore is located in the south end of Asia, with area $719.1 \mathrm{~km}^{2}$, and it is ranked the third in human population density with $5,535,000$ inhabitants [14]. It is an island country since it's mostly surrounded by sea water. Climate of Singapore is tropical with high humidity and a lot of rainfall with average of $2,400 \mathrm{~mm}$ annually [15]. Due to its strategic location Singapore has a high developed market economy, and it is a global financial, commerce and transportation hub [16]. Singapore is high on key measures of national social policies, that ranks $9^{\text {th }}$ globally on human development index and leading Asia on human development index. In addition Singapore received Stockholm Industry Water award, for its holistic approach to water resources management [17]. Singapore's freshwater approach doesn't rely on physical infrastructure only, but also stress on proper legislations and enforcement, water pricing, public education, and research development programs. Water in Singapore is considered easily accessible, affordable, efficient and very high in quality [15]. Fresh water concerns started in the 1868 were Singapore build their first reservoir called MacRitchie reservoir, also known as impounding Reservoir, since it used to pound water from the Earth. As the demand grew a new reservoir was considered, in 1910 Lower Peirce Reservoir was constructed, following this step in 1927 Singapore came to an agreement with Malaysia to rent a land in Johor, to benefit from the existing water sources, in return Singapore will supply Malaysia with small return of treated water, so a pipeline was constructed in 1932 linking Singapore with Johor, with a water treatment plant in Singapore. In the 1940 Upper Seletar Reservoir was constructed to supply the fast growing population. Singapore battle in 1942 blew up the pipe lines [18]; this was the first motive for Singapore to develop their local water resources in 1963 they reconstructed the pipelines, in addition to expanding them with two new water treatment plants built in Singapore[18], Since Singapore was to become a part of Malaysia, after the war ended. After shortly 2 years of becoming part of Malaysia they broke up, and Malaysia started applying pressure on Singapore by demanding more money, and threatening to cut the water supply [19]. This was the second motive for developing the local water resources. At first the better choice was to increase the amount payed for the imported water, since desalination of sea water was much more expensive. After they became afraid of losing the import of water in 1963 till 1981, 5 dams were built as an initial strategy for having their own fresh water sources [18]. The third and final motive was in 1998, when Singapore was looked forward to extending the agreement with Malaysia beyond 2011 to 2060. Malaysia raised the price once more, it was still slightly better than seawater desalination process [18]. In addition to these motives Singapore as mentioned before it have a good quantity of rainfall, but on the other hand it's a very dense country which means the area for water catchments is very limited. Furthermore there are no natural aquifers or lakes to store this large quantity of water. Therefore the government adopted a strategy called "Four Taps" to supply fresh water. In 2002 while the negotiations with Malaysia were still ongoing, Singapore started to prepare for self-sufficient local water resources, through integrated water management strategies as water reuse and desalination of seawater. A study by the 
government was conducted for reclaimed water "used-water" treatment to potable water if it is a viable source of fresh water this process was called NEWater [20]. "Four Taps" process was initiated by the ministry of environment of Singapore in 2002. $1^{\text {st }}$ Tap was the local water catchment from rainfall. $2^{\text {nd }}$ Tap was water importing which already existed. $3^{\text {rd }}$ Tap is the reclaimed water treatment "NEWater", that was active after 2 years of carful testing, to ensure safe water quality. $4^{\text {th }}$ Tap is the seawater desalination plant, which opened in 2005. In the same year Marina Bay Reservoir, the largest reservoir " 1 st Tap", expanded, located on Estuary River and closed by barrage to separate fresh water from seawater. 2 similar barrage were constructed in 2011 Punggol Reservoir and the Serangoon Reservoir. When the agreement with Malaysia ends in 2061, Singapore will be self-sufficient and it will not need to extend it. Therefore, the main supplying fresh water methods are:

\section{1) 1st Tap local water catchments}

In 201217 reservoirs Singapore's were already functioning, treated with chemical coagulation, rapid gravity filtration and disinfection. Oldest reservoirs like MacRitchie [21], Lower Peirce, Upper Selatar and Upper Peirce Reservoirs are all located in a protected area with greenery, to improve the cities air quality, found in the Central Catchment Nature Reserve. River estuaries encompass other larger reservoirs, and are closed by barrages. Most of the country's surface area is classified catchment areas, with certain policies of the on land use, it is protected land so that the rainwater can be collected and used as drinking water. Storm water collection system is separated completely from the sewers. Cover $7,000 \mathrm{~km}$ of roadsides and $1,000 \mathrm{~km}$ of major canals and water ways. It is always maintained and clean, this system reduced the floods in Singapore significantly 3,200 hectares of flood area in 1970 reduced to only 40 hectares in 2013 [22].

\section{2) $2^{\text {nd }}$ Tap imported water}

Singapore imports water from Johor in Malaysia through a pipeline that is $1 \mathrm{~km}$ along the Johor Singapore Causeway. As of 2009 , imported water had been reduced from $50 \%$ previously to $40 \%$ of total consumption [19]. 2 agreements are still in progress, one was signed in 1962 and another one in 2000. Both will expire in 2061. Under the first agreement the price of natural water is set at a very low rate of 0,2 US cents per 1,000 $\mathrm{L}$ [19]. Under this agreement Singapore is entitled to receive up to $1,100,000 \mathrm{~m} 3$ per day, corresponding to $66 \%$ of its water use that is $1,700,000 \mathrm{~m} 3$ in 2011 . Frankly Singapore received in 2011 only 680,000m3 less than the amount agreed amount.

3) $3^{\text {rd }}$ Tap Reclaimed Water Treatment "NEWater"

Used-water in Singapore is called Reclaimed water, Treated in conventional innovated waste water treatment plant, using Dual-membrane that is "via microfiltration and revered osmosis", and ultraviolet technology, resulting in ultra-pure water called NEWater. The quality of NEWater is carefully monitored by international experts. NEWater surpassed the WHO standards for drinking water. In 2012, four NEWater factories, located at the Kranji, Bedok, Changi, and Ulu Pandan next to five water reclamation plants. Most of the
NEWater is used by industries for non-potable uses such and wafer fabrication, which lowered their production cost. In 2008 NEWater provided $30 \%$ of the required water [20]. The dispersed water reclamation plants and NEWater factories are gradually closing and replaced by a single, much larger water reclamation plant and NEWater factory at Changi. Deep Tunnel Sewerage System is constructed this plant.

\section{4) $4^{\text {th }}$ Desalination of Seawater}

On 13 September 2005, first desalination plant started SingSpring Desalination Plant in Tuas at the southwestern of Singapore, Can produce $140,000 \mathrm{~m} 3$ of water each day and meets $10 \%$ of the country's water needs. In 2013 the second and largest desalination plant, Tuaspring Desalination Plant, also in Tuas, with a capacity of $320,000 \mathrm{~m} 3$ per day [23]. Together, desalinated water from SingSpring and Tuaspring provide up to $25 \%$ of Singapore's current water needs. Five future plants, with the objective of bringing the installed capacity to 1 million $\mathrm{m}^{3}$ per day, so that they can supply for up to $25 \%$ of Singapore's future water demand by 2060.

\section{5) Public Education for fresh water Conservation}

After all the measures taken by the government of Singapore, public education and water management campaigns were given to people, furthermore the method of water efficiency labeling was done as well to help people choose wisely. This led to water preservation from $165 \mathrm{~L}$ per person in 2003 to $155 \mathrm{~L}$ per person 2009 [24]. These strategies made only $5 \%$ of waste water "non-renewable water"; Singapore is considered one of the lowest countries to waste water in the world.

The government of Singapore insured that the collected water won't get polluted, by handing the sanitation and storm water drainage to the same agency to carefully monitor them. In addition, Singapore government constructed the Deep Tunnel Sewerage System, DTSS, in 2010 [25], instead of traditional sewage system, that is 20 to 55 meters below ground, and $48 \mathrm{~km}$ long, no use of any pump only gravitational energy, connected to Changi reclamation plant.

Singapore is now a global water research and technology with governmental support.

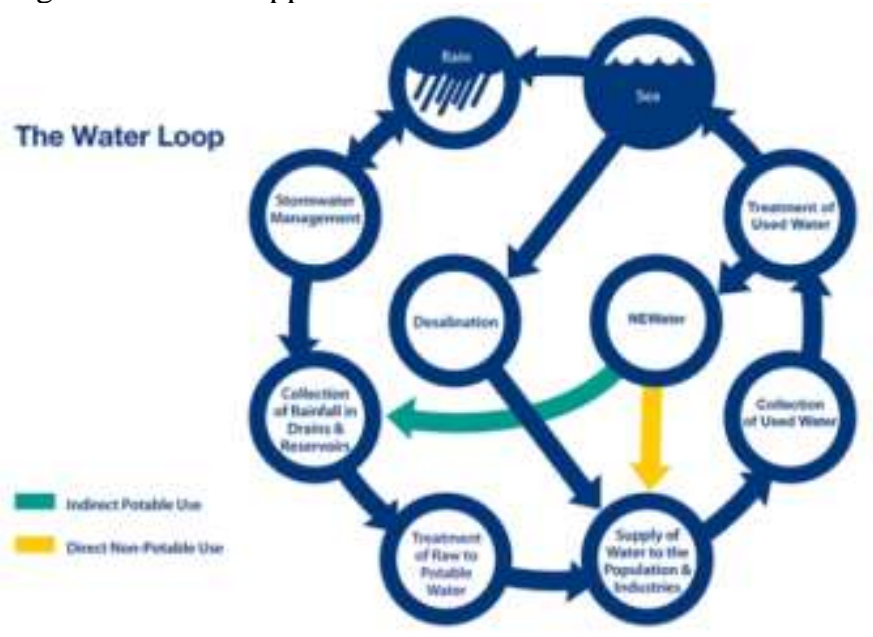

Fig. 3: Singapore Freshwater loop, http://www.pub.gov.sg/water/Pages/default.aspx 


\section{B. Second case study: Experience of Netherlands}

Netherlands is one of the countries that have an abundancy of water, from rivers to lakes and even sea water. Their methods could be applied for some developing countries that have a large amount of fresh water but are not taking advantage of. Netherland lies in the west of Europe, with an area of $41,543 \mathrm{~km}^{2}$, including 3 islands, has a population of $16,969,859$ inhabitant [26], its considered as small and very dense country, $30^{\text {th }}$ most dense country, with density of 407.7 persons per square kilometer. The climate in Netherlands is considered as a moderate maritime climate, with high humidity cool summers and slightly cold winters. Netherlands is known as one of the happiest countries, ranking $4^{\text {th }}$ on having high quality of life globally [27]. Although it have a high number of population, Netherlands ranks $2^{\text {nd }}$ in the world in exporting food and agriculture[28], in addition it's the number 1 country on the Euro health consuming index. Furthermore, Netherlands is the $13^{\text {th }}$ highest per capita income in 2013, playing a major role in Europe's economy from shipping, fishing agriculture, trade and banking. And it has the largest port in Europe. Nevertheless the Netherlands has 20 natural parks and over a hundred natural reserves like, lakes, rivers, forestry, dunes and heathland etc. and characterized by its rich biodiversity.

Geographically Netherlands is mostly located under sea-level, with only $29 \%$ of land is below sea level $26 \%$ are critical areas for flooding lower than $1 \mathrm{~m}$ of sea level. $17 \%$ of existing land is man-made, by draining parts of lakes, rivers and swamps, mostly turning them into farm lands [29]. The southwest part of Netherlands is a delta of 3 rivers, Rhine, Meuse, and Scheldt delta. Rhine and Waal River are named the Great Rivers, since they cut Netherlands into half. Due to the large amounts of water Netherlands had encountered many natural disasters; on top of it are the floods, one of the floods killed over 50,000 people [30]. Making farming very difficult, floods wiped out many farm lands. Netherland is the one of the most countries that will be affected by Global Warming and climate change. not only from the rise of the sea levels but also from the rivers over flooding, it is the only country that is working very hard for the rising of sea levels to prevent disasters. As a matter of fact people back in the $13^{\text {th }}$ century people started making sophisticated systems and natural infrastructure to reduce the flooding disasters and keeping the lands dry. First method in the $13^{\text {th }}$ century to avoid the over flow of rivers and seawater harming the farm lands, they used windmills to pump the water prom rivers and under sea level lands, they mostly used the pumped water in irrigation and dumping it in the sea, these lands were then turned into polder. In 1953 another massive flood occurred [30], so the government proposed a project that could reduce the floods, produce clean energy and supply fresh water, this project is called Delta Works, construction began in the 1958 and took around 30 years to get completed. It ended up to be the largest flood protection project with more than 16,500k of levees and 300 structures, approximately $3,000 \mathrm{~km}$ of outed sea duke, and $10,000 \mathrm{~km}$ inner canals and rivers dike [31]. It's considered among the seven wonders of the modern world by the American Society of Civil Engineers. Another project was made for flood reduction, master landscaping and improvement of the environmental conditions, and maintains equal water distribution between Rhine and Moselle rivers, called Room for the River, a $\$ 2.48$ billion program [31]. Started in 2006 and will be completed in 2015, it's a collaboration between national and regional governments, research institutions, businesses and the citizens; it is a highly innovative water management systems [32]. Fresh water in Netherlands is easily accessible, with very high quality. Fresh water pricing was relatively high in the past, but a reduction in the cost was made. $60 \%$ of fresh water supplying Netherlands is extracted from underground, mainly in the east part of the country. The other $40 \%$ comes from the treatment of surface water resources, which is pumped mainly from the Rhine and Meuse rives, in the west side of the country, since the underground water in the west of Netherlands is slightly salty. Fresh water treatment and supply is carefully managed, cleaned and maintained, the network is very good in shape, and as a result water delivered to people is not chlorinated to prevent recontamination after treatment [33]. Water consumption in Netherlands is one of the lowest in developing countries $128 \mathrm{~L}$ per person per day, nevertheless it is considered among the top countries with lowest wastewater "nonrevenue water". The annual investment for water treatments and supply is around 350 million USD, Managed by 10 regional companies and 27 water boards for water management. Held previously in 1945 by more than 200 companies, this number decreased to 10 companies after only 5 years, after the transition from under sources of fresh water supply to surface fresh water supply, which in terms led to huge investments and required more complex treatment plants. In addition the benchmarking of the companies and their competitiveness in the European market narrowed down the number of companies. Netherlands have many factors affecting fresh water supply strategy [33]. Therefore, the Dutch supplying fresh water methods are:

\section{1) Netherlands water Infrastructure}

The Netherlands water pipe system has a low leakage rate between 3\% and 5\%, below other European countries average of $10 \%$, this is because of new sensor technology and regular maintenance of the pipes that extends around 116,000 km [33] , [34]. The first fresh water supply infrastructure was constructed 1853 in Amsterdam. Water was extracted from the sand dunes, because of the filtering properties of the fine sand. Three cities followed Amsterdam, Den Helder, The Hague and Rotterdam. In 1900 the first water closet was connected to a sewer system, and construction of a sewage system began in Amsterdam in 1910. About 710 municipalities were connected to the main water supply, which means that $75 \%$ of Netherlands population had access to fresh water in 1949 [35].

\section{2) Netherlands knowledge infrastructure}

Netherlands developed a good knowledge infrastructure in the water supplying sector, including government and private research centers, technological and educational institutes and several universities. These institutes come out with applied research, because cities in the Netherlands are too populated, 
they are constantly looking for creative and innovative ways to treat wastewater using less space, in addition to integrated water management, freshwater treatment, flood control, flood protection, foundation technology infrastructure and hydraulic engineering. These facilities and institutes formed close connections with internationally oriented private companies. Not only do these institutes apply their experience inside Netherlands but as well at an international scale, they share information and research with several international institutes. Many researches were applied, for example membrane technology, anaerobic water purification, membrane bioreactor and Anammox technology. Netherlands private firms are also recognized for their cutting edge R\&D [34].

\section{3) Wastewater Treatments}

In the 1970s innovative waste water treatment system was introduced, the good quality treated water is used in irrigation, industries, food and beverage production. A new less expensive highly effluent water treatment plant in Emmen that needs less space now operates. The effluent from this wastewater treatment plant is purified to get ultrapure water about 3 million $\mathrm{m}^{3}$ per year. Faster, cleaner and less expensive [34], [35]. Water from hospitals is treated directly onsite, this process includes shredders instead of bed washers, flushed down in the sewage system a fermentation installation decontaminates the solid wasted and produces biogas, then the waste water is purified and cleaned of medicinal remains. This process is called Pharmafilter, economically and environmentally more efficient than the traditional sterilization [36], [35]. Another process called concentrated, for industries and household wastewater, which is to keep the waste as solids and not letting them dilute by anyway. Then the concentrated waste water is then processed by anaerobic and aerobic techniques, these techniques also generate biogas energy [35]. Due to a strict policy by the European water requirements, nitrate and phosphate must be removed from the water; a research had been conducted at Delft University of Technology, and Anammox bacteria that help in converting these substances into nitrogen gas was deducted. This is also very important for regions with no or bad sewage systems [35]. Nevertheless, Membrane Technology which is a sustainable approach to purify waste water. This research was done by the PWN Technologies in Netherlands. This process works on filtering wastewater from an organic solution such as hexane and ethanol, using polymer membrane, this ceramic membranes plant purify 120 million liters per day.by applying Desalination it will be a solution for providing fresh water [35].

Furthermore sewage water is purified with no chemicals used in this innovative technology, to produce $10,000 \mathrm{~m}^{2}$ per day of ultrapure water. This technology is used in place of purifying surface water, to maintain the level of water in the rivers in dry summer times. Netherlands purify and clean all the waste water coming from industries, hospitals, and households; no matter what they contain they can be cleaned.

\section{4) Water institutes and benchmarking}

There are 10 regional institutes for fresh water supply, in 1997 began to benchmark their performance against each other and against other European companies. The Ministry of Economic Affairs proposed the signing of a regulatory agency, for this main reason the companies started to improve their operation; this included enhancing their efficiency, increase transparency, better water quality, improved services, environmental protection, sustainable waste water treatments and financial statues. This inspired many international companies globally. And they are well recognized for their treatment expertise [37]

\section{5) Government role in Fresh water supply}

None of the water management techniques could be employed and effective if it weren't for water boards. The government plays a crucial role in maintaining the high standards of water supply, water quality, and waste water, in addition controlling the flood protection projects. It's one of the oldest public authorities in the Netherlands; as well have a strong consultation and cooperation system between stakeholders, citizens, research facilities and other organizations. This integration is made to ensure the safety and satisfaction of all residents [37].

Water boards are in charge of their respective regions, they plan and state guidelines to provide a well-structured supplying system, with considerations of environmental protection. They also apply a specific levy taxes, for cost recovery, for struggles. A regulatory agency was proposed to safeguard the water system. Of generated a law in 2004 banning private delivering of fresh water supply [37].

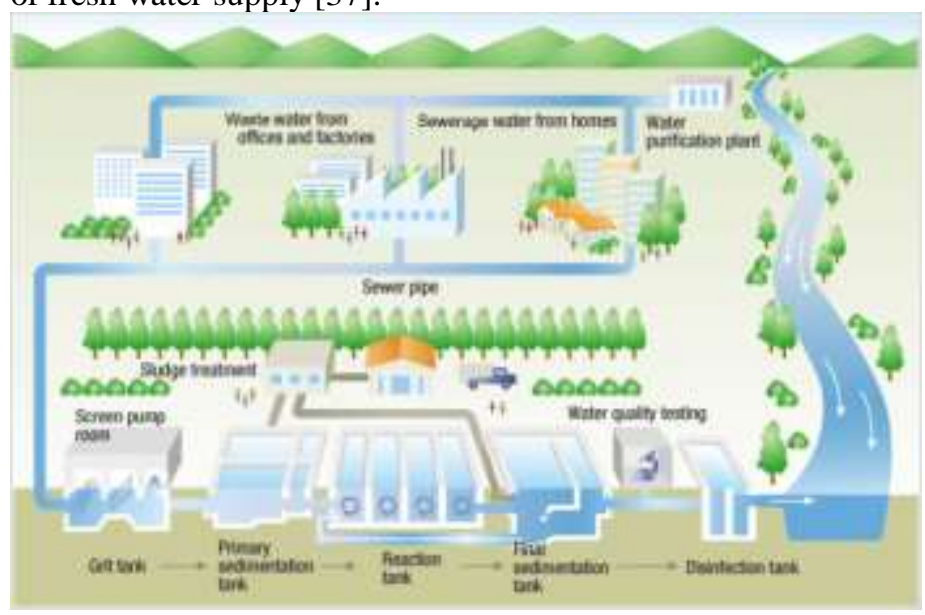

Fig. 4: Freshwater Loop in Netherlands

http://www.hitachi.com/environment/showcase/solution/industrial/pegasus.html

\section{CONCLUSION}

The previous case studies presented several fresh water supplying systems and approaches. These methods can be implemented by the developing countries, not all of these methods are expensive, some doesn't use money at all, like in the case of Netherlands one of the best things is that they have a good controlling government, which managed the water integrated systems carefully. And by forming water board that supervised constantly over the water systems institutions. Nevertheless the board integrated the knowledge infrastructure with the companies, government, organization and research facilities. This structuring procedure from the government 
doesn't need money or very few amount of money.

In addition Netherlands companies have a competitive mentality that was acquired due to several reasons, one of which the government could hire several water companies to achieve this competitiveness, and put a regulatory agency to control the water quality and distribution of these companies.

The government could lunch public education and water management campaigns, like in Singapore this was somehow an effective approach, every country no matter the financial statues could lunch these awareness campaigns, and make efficiency labeling, to help people choose wisely. In addition to all these un-embodied infrastructure, developing countries could implement some affordable physical strategies as well, for example both case studies have a low rate of leakage in their infrastructure with reduces the amount of waste water, nevertheless it will reduce pollution coming from sewage that could contaminate the water supply and aquifers, in addition rainwater catchment will be managed easier and not polluted, with few treatment procedures they will supply a significant amount of fresh water depending on the precipitation levels and the country area. On the other hand some treatment methods can be applied for reclaiming water with minimum space required and affordable cost like in Singapore case for NEWater this could bring some income to the country by selling bottled water.

In both case studies it was intensively taken advantage of the knowledge infrastructure, by financing research facilities and making competitions, which gave many applied research, this may generate a huge return for the country by making innovative treatments.

We are facing global warming and climate change; these effects will make developing countries suffer terribly, from the rise of sea levels, floods and intrusion of sea water to the underground aquifers that will result in loss of fresh water. So it's time for developing countries to take counter measures and prepare for the upcoming shortage of fresh water.

\section{REFERENCES}

[1] World's 36 Most Water-Stressed Countries by Paul Reig Paul Reig, Andrew Maddocks and Francis Gassert - December 12, 2013

[2] World Health Organization. (2006). Meeting the MDG drinking water and sanitation target: the urban and rural challenge of the decade. Retrieved from the website:

http://www.who.int/water_sanitation_health/monitoring/jmpfinal.pdf

[3] IPCC, AR4, WGIII. (2007). Summary for Policymakers of the Synthesis Report of the IPCC Fourth Assessment Report, Draft Copy, 16 Nov 2007-subject to final edit.

[4] The Millennium Development Goals Report 2012 by the unitd nations http://www.un.org/en/globalissues/water/

[5] Awuah, E., Nyarko, K.B., Owusu, P.A., \& Osei-Bonsu, K. (2009). Small town water quality. Desalination, 248, 453-459. http://dx.doi.org/10.1016/j.desal.2008.05.087

[6] The united nations global issues water http://www.un.org/en/globalissues/water/

[7] Abramovitz, Janet. (1996, March). Imperiled waters, impoverished future: The decline of freshwater ecosystems (Worldwatch Paper No. 128). Washington, DC: Worldwatch Institute

[8] Gardner-Outlaw, Thomas \& Engelman, Robert. (1997). Sustaining water, easing scarcity: A second update. Washington DC: Population Action International

[9] Kristen Erickson, Last Updated: May22, 2013National Aeronautics and Space Administration (NASA),

http://science.nasa.gov/earth-science/oceanography/physical-ocean/salinity/
[10] Shiklomanov IA, Rodda JC, 2003. World Water Resources at the Beginning of the Twenty-first Century. Cambridge (United Kingdom): Cambridge University Press.

[11] Pimentel D, Berger B, Filiberto D, Newton M, Wolfe B, Karabinakis E, Clark S,Poon E, Abbett E, Nandaopal S . 2004. Water Resources, Agriculture, and the Environment. Ithaca (NY): New York State College of Agriculture and Life Sciences, Cornell University. Report 04-1.

[12] Myers N, Kent J . 2001. Perverse Subsidies: How Tax Dollars Can Undercut the Environment and the Economy. Washington (DC): Island Press.

[13] ARENE (2005), Quartiers durables. Guide d'expériences européennes, Paris, (available at

http://www.areneidf.org/HQE-urbanisme/pdf/qde-exp-europe.pdf

[14] "Statistics Singapore - Latest Data - Population \& Land Area (Mid-Year Estimates)". Statistics Singapore. June 2014. http://www.singstat.gov.sg/statistics/latest-data\#14

[15] Ivy Ong Bee Luan (2010). "Singapore Water Management Policies and Practices". International Journal of Water Resources Development 26.

[16] Li, Dickson (1 February 2010). "Singapore is most open economy: Report". Asiaone (Singapore). https://web.archive.org/web/20100207003624/http://www.asiaone.com:80/ Business/News/My+Money/Story/A1Story20100201-195831.html

[17] Stockholm International Water Institute: Stockholm Industry Water Award. http://www.siwi.org/sa/node.asp?node=83

[18] "Singapore's Water Cycle Wizardry," by Sandra Upson, IEEE Spectrum, June 2010 http://spectrum.ieee.org/energy/environment/singapores-water-cycle-wizardr y

[19] Valerie Chew:Singapore-Malaysia water agreements, Singapore Infopedia. This is based on an exchange rate of 3.11 Malaysian Ringgit per US dollar, as of August 2012 http://infopedia.nl.sg/articles/SIP_1533_2009-06-23.html

[20] '2007/2008 PUB Annual Report". Public Utilities Board. http://www.pub.gov.sg/mpublications/Pages/AnnualReport.aspx

[21]Development of Water Supply Infrastructure: MacRitchy Reservoir History, http://members.tripod.com/yuhe_mubarak/photogallery/MacRitchie\%20Res evoir\%20History.htm

[22]Channelnewsasia.com (24 December 2011). "Managing flash floods is PUB's priority: CEO"

[23] PUB Press Release (6 April 2011). "PUB and Hyflux sign Water Purchase Agreement for Singapore's second and largest desalination project". http://www.pub.gov.sg/managingflashfloods/FMS/Pages/MaintenanceRegi me.aspx

[24] Public Utilities Board: Conserve, accessed http://www.pub.gov.sg/conserve/Pages/default.aspx

[25] "Milestones: Largest and most advanced water reclamation plant in Southeast Asia". Public Utilities http://www.pub.gov.sg/ABOUT/Pages/Milestones.aspx

[26] "Population counter". Centraal Bureau voor de Statistiek. Checked on (Nov.13-2015)

[27] Helliwell, John; Layard, Richard; Sachs, Jeffrey (9 September 2013). "World Happiness Report 2013"

[28] Netherlands: Agricultural exports top 80 billion Euros, Publication date: $1 / 19 / 2015$

[29] Netherlands Guide - Interesting facts about the Netherlands". Eupedia. 19 April 1994.

[30] Britannica Encyclopedia Zuiderzee floods (Netherlands history).

[31] Kimmelman, Michael (13 February 2013). "Going With the Flow". The New York Times

[32] CITISCOPE.ORG meeing new minds (A Dutch city makes room for its river - and a new identity) http://cityminded.org/a-dutch-city-makes-room-for-its-river-and-a-new-ident ity-13348 visited on Nov. 10-2015

[33] VEWIN Water Supply Statistics Association of Dutch Water Companies Sir Winston Churchilllaan 273, Netherlands, 2008

[34] Association of Dutch Water Boards

[35] Royal Netherlands Embassy http://waterandthedutch.com/water/ visited on Nov. 10-2015

[36] Pharmafilter Results of the demonstration project at Reinier de Graaf Hospital, Delft, the Netherlands, in April 2012 


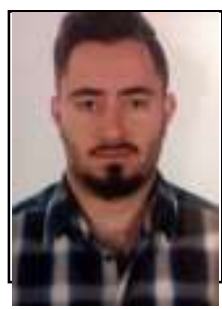

A. Sidani from Lebanon / 28 Jan. 1991. Bachelor degree of Architecture, 2015, Beirut Arab University, Beirut, Lebanon. $\mathrm{He}$ is an AECHITECT and a POSTGRADUATE STUDENT completing his masters degree at the Faculty of Architectural Engineering, Beirut Arab University.

He is currently working as a FREELNCE ARCHITECT on small construction projects in Lebanon, worked the last four summers at the Arabian Construction Company, as a SITE ENGINEER at Wadi Hills, and Mina El-Hoson, and QUANTITY SURVAYING in Eauone project.

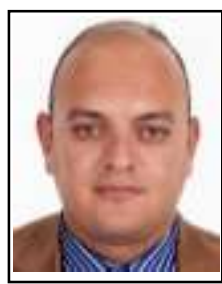

Second Author: M. Youssef

Dr. M. Youssef is from Egypt / 21 Nov. 1981. Bachelor degree of Architecture, 2003, Ain Shams University, Cairo, Egypt.

M.Sc. of Architecture, 2009, Ain Shams University, Cairo, Egypt, in the field: 'history and theory of architecture'

$\mathrm{PhD}$ of Architecture, 2012, Cairo University, Cairo, Egypt, in the field: 'history and theory of architecture and philosophy of architectural design'.

$\mathrm{He}$ is an ARCHITECT and a LECTURER teaching courses of (Architectural Design) and (Theory of Architecture) at the Faculty of Architectural Engineering, Beirut Arab University, Lebanon. He published many articles in international conferences and architectural journals; such as:

'The Power of Manual Sketching in Design', The International Journal of Design Education, Vol.7 Issue no.1, Illinois, USA, Common Ground Publishing, 2013

'Language of Minimalism in Architecture', Journal of Engineering and Applied Science, Faculty of Engineering, Cairo University, Cairo, Egypt, 2015.

'How can one building change a city from locality to internationality?', ARCHTHEO' 2015 Conference, Dakam, Istanbul, Turkey, 2015.

In addition, he published a book in Arabic language under name:

'Effect of Ancient World Mythology on the Contemporary Architectural Design Concepts', Dar Al-Fikr Al-Arabi, Cairo, Egypt, 2009.

The previous research interests: philosophy of architectural design, interpretations, metaphor, mythology, intentions, spirituality, and religions.

The current research interests: new construction technology, digitalization, criticism, iconology, politics, and parapsychology.

Dr. Youssef travelled to many countries around the world which let him gain a criticizing architectural character. Lately, he led a group of 24 students from the Faculty of Architectural Engineering, Beirut Arab University, Lebanon, in an oversea summer school in Cardiff, UK, 2015. It was entitled: LCASP; Low Carbon Architecture Summer Programme, hosted by the Welsh School of Architecture, Cardiff University, UK. 